\title{
Carbon-Epoxy Composites Reinforced with Nano-Structures of Tungsten Disulfide for Potential Use in Aircraft Structures
}

\author{
Milica Marjanović ${ }^{1)}$ \\ Danica Simić ${ }^{1)}$ \\ Srđa Perković ${ }^{1)}$ \\ Jela Galovic ${ }^{1)}$ \\ Zijah Burzićc \\ Ana Tasić ${ }^{1)}$ \\ Slađan Grga ${ }^{1)}$
}

\begin{abstract}
In design of aircraft it is important to use light-weight, but mechanically strong materials and for this purpose, many new composite structures have been developed, mostly based on strong fibers and a binding resin. In this research a possibility is considered to reinforce composite based on carbon fibers and epoxy resin, adding a small amount of poly (vinyl butyral), PVB and nanostructures of tungsten disulfide. Two kinds of nanoparticles were used in experiments, both known by their good mechanical resistance: fullerene-like nanoparticles and multi-wall nanotubes, IF-WS2 and INT-WS2. Composite samples were prepared to consist of multi-layers of carbon fibers impregnated with epoxy resin and PVB solution containing dispersed nanostructures of WS2 in defined concentrations. Nanoparticles have been observed with scanning electron microscope, SEM. Mechanical properties of the multi-layer composite samples have been tested with two configurations of fiber directions. Analysis has been made to compare results and give conclusions that encourage the future application of these nanostructures to enhance the performance of composites for military aircrafts.
\end{abstract}

Key words: composite materials, nanoparticles, tungsten disulfide, epoxy resins, carbon fiber, aircraft structure.

\section{Introduction}

$\mathrm{C}$ OMPOSITE materials for design of aircraftsare most often based on high performance fibers, such as carbon, glass or aramid fibres and fabrics, impregnated with a polymer matrix [1,2]. In the Military Technical Institute in aviation projects composite materials are used for decades for making complex shapes of composite structures for the production of unmanned short and medium-range aircrafts [3, 4]. These composites are used instead of metal materials in order to obtain a strong and lightweight structure of the aircraft. In this paper a research is presented considering possibility of making a hybrid composite material withim proved mechanical properties, based on carbon fibers impregnated with PVB modified epoxy resin reinforced with inorganic multi-layer nanotubes of tungsten disulfide (INT$\mathrm{WS}_{2}$ ) and its fullerene-like nanoparticles (IF-WS 2 ). New composite materials for use on aircrafts were tested through comparation of mechanical properties and analysis of the behavior of composite materials with nanostructures of $\mathrm{WS}_{2}$ and without them, during static and dynamic tests.

Carbon fibers in combination with epoxy resin are widely used in aircraft construction. Epoxy resins are among the most widely produced thermosetting resins, due to its ease in processing, high mechanical and adhesion characteristics, good electric insulating properties, chemical resistance and relatively low shrinkage during curing [5]. However, epoxy resin itself, is brittle, multiple microcracks initiation and growth takes place during the epoxy products exploitation, which results in the premature product failure. Epoxy toughness may be enhanced by introduction of rubber modifiers, active diluents or thermoplastic polymers, such as poly(vinyl acetate) and poly(vinyl butyral) [5] .

Poly (vinyl butyral) is known by its good adhesion, good tensile strength and elasticity, and due to these properties it is widely used in different types of coatings, binders, as well as a polymer matrix in composite materials for ballistic protection [6-10]. These advantages made PVB a good candidate for combination with epoxy resin, with which it reacts according to structural formula in Fig.1, preventing its brittle fracture and enhancing its impact resistance [6].

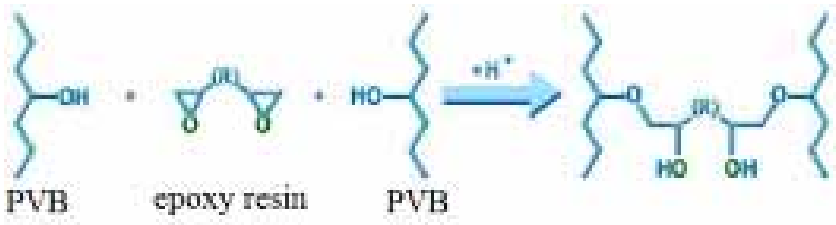

Figure 1. Reaction between PVB and epoxy resin

Tungsten disulfide in the form of multiwall nanotubes and fullerene-like spherical nanoparticles has been lately studied for a wide range of applications due to its extraordinary properties [11-15]. The following properties are important for their application as reinforcement in aircraft composite

\footnotetext{
1) Military Technical Institute (VTI), Ratka Resanovića 1, 11132 Belgrade, SERBIA

Correspondence to: Milica Marjanović; e-mail: milicagoran@gmail.com
} 
structures: high pressure, impact and heat resistance; high shock absorbing abbility, thermal stability, chemical inertness, compatibility with various systems. These properties were recognized in earlier researches when they were already used as reinforcement of polymer composites and coatings [16-19]. From the aspect of their application in composite system planned in this research, it is important to say that it has been proven that nanostructures of $\mathrm{WS}_{2}$ significantly enhance properties of PVB, that will also be used for new composites manufacture $[17,20]$.

\section{Experiments and methods}

\section{SEM analysis}

Before their application in the composite material, nanoparticles and nanotubes of WS2 (as received) were observed by scanning electron microscope (SEM) JEOL JSM6610 LV. The particles were gold-plated and observed under a voltage of $10-15 \mathrm{kV}$, under various magnifications.

\section{Composites manufacture}

For the composite samples preparation within this research, the following materials were used:

- unidirectional carbon-epoxy prepreg (areal density 450g / $\mathrm{m}^{2}$, produced by HAUFLER Carbon fiber / Epoxy UD prepreg K63712),

- tungsten disulfide manufactured by Nanolub, ApNano, Israel, IF-WS ${ }_{2}$ and INT-WS 2 , typical nanoparticle diameter nanotube outer diameter 80-100 $\mathrm{nm}$ and length 10-20 $\mu \mathrm{m}$, insoluble in oil, grease, silicone fluids, alcohols and fuels.

- PVB powder, manufactured by Kuraray GMBH, type Mowital $\mathrm{B} 45 \mathrm{H}$, and

- ethanol produced by Zorka Sabac.

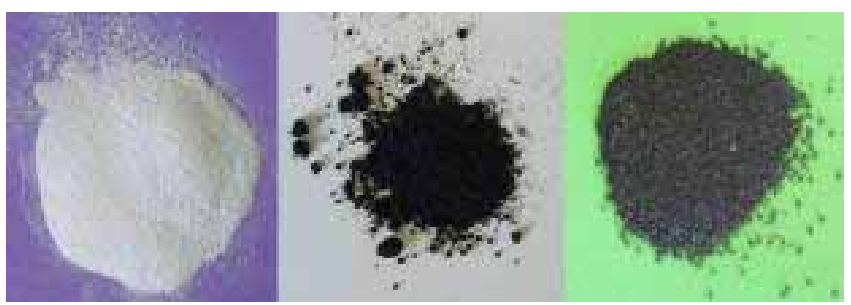

Figure 2. From left to right: PVB, IF-WS $\mathrm{W}_{2}$ and INT-WS

IF-WS $\mathrm{W}_{2}$ and INT-WS $\mathrm{W}_{2}$ were subjected to a 30 minute ultrasonic dispersion and deagglomeration in ethanol with ultrasonic probe Badelin SonoPuls (Fig.3a). Subsequently, the vessel containing ethanol with tungsten disulphide was transferred to the magnetic stirrer, and during the mixing, an appropriate amount of PVB powder was added gradually (Fig.3b). PVB powder was added to make $10 \mathrm{wt} . \%$ solution in the present amount of ethanol. This solution was evenly applied on carbon-epoxy prepreg using a flat spatula. In this system, a small amount of nanostructures was used, only 1 wt. $\%$ of IF-WS $\mathrm{WS}_{2}$ and 0.3 wt. $\%$ of INT- $\mathrm{WS}_{2}$ regarding the mass of polymer matrix (PVB and epoxy resin together). After complete evaporation of ethanol from the impregnated prepregs, samples of laminar structures for structural analysis and mechanical testing were made, consisting of 8 layers of carbon unidirectional prepreg with PVB with and without nanostructures of $\mathrm{WS}_{2}$. They were subjected to pressure on the Belišće Thermal Press (Fig.3c). The laminated composite structures were formed by a hot press molding technique under a defined pressure of 5 bar and at a temperature of $130^{\circ} \mathrm{C}$. The orientation of fibers was $90^{\circ}$ and $0^{\circ} / 90^{\circ}$.

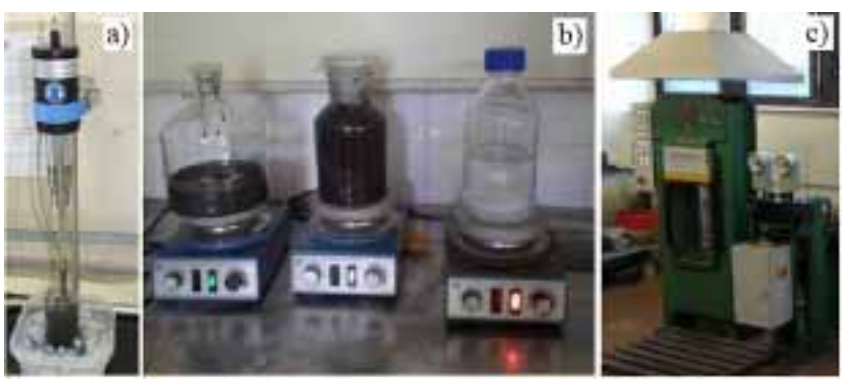

Figure 3. a) Ultrasonic dispersion of WS2 nanoparticles, b) dissolving PVB in ethanol with and without nanostructures of $\mathrm{WS}_{2}, \mathrm{c}$ ) Belišće Thermal Press
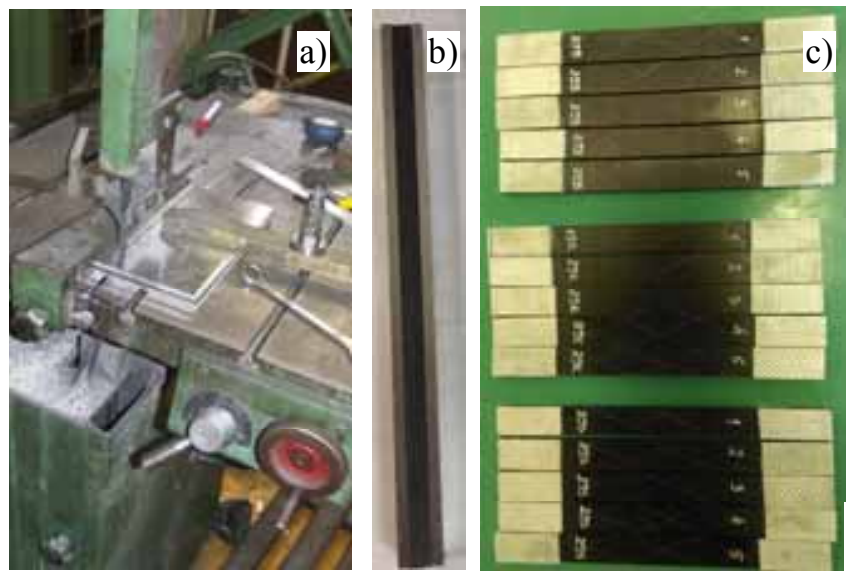

Figure 4. a), b) cutting composite samples between aluminum plates, c) test specimens

The obtained samples were cut into test specimens in accordance with ASTM D 3039 standard [21] - tightening the composite samples by placing them between aluminum plates in order to avoid deformation and friction during cutting (Figures 4a, 4b). Tabs added at the ends of the tubes entering the clamps are made of glass fabric with epoxy resin, cut and glued, with mixture of Araldite AW 106 and Hardener HV $953 \mathrm{U} \mathrm{BD}$, to the test specimens (Fig.4c).

For tensile testing SHIMADZU SERVO PULSER was used (Fig.5), at tensile speed $1 \mathrm{~mm} / \mathrm{min}$ and pressure in the clamps 9 bar.
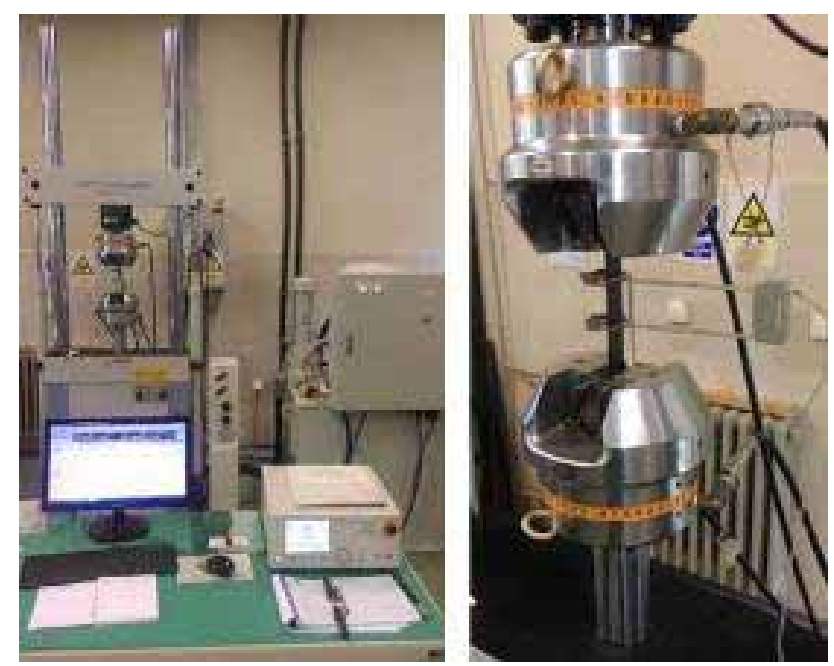

Figure 5. Tensile testing on Shimadzu Servo Pulser

\section{Results and discussion}

SEM images of tungsten disulfide nanoparticles and nanotubes are given in Fig. 6. 

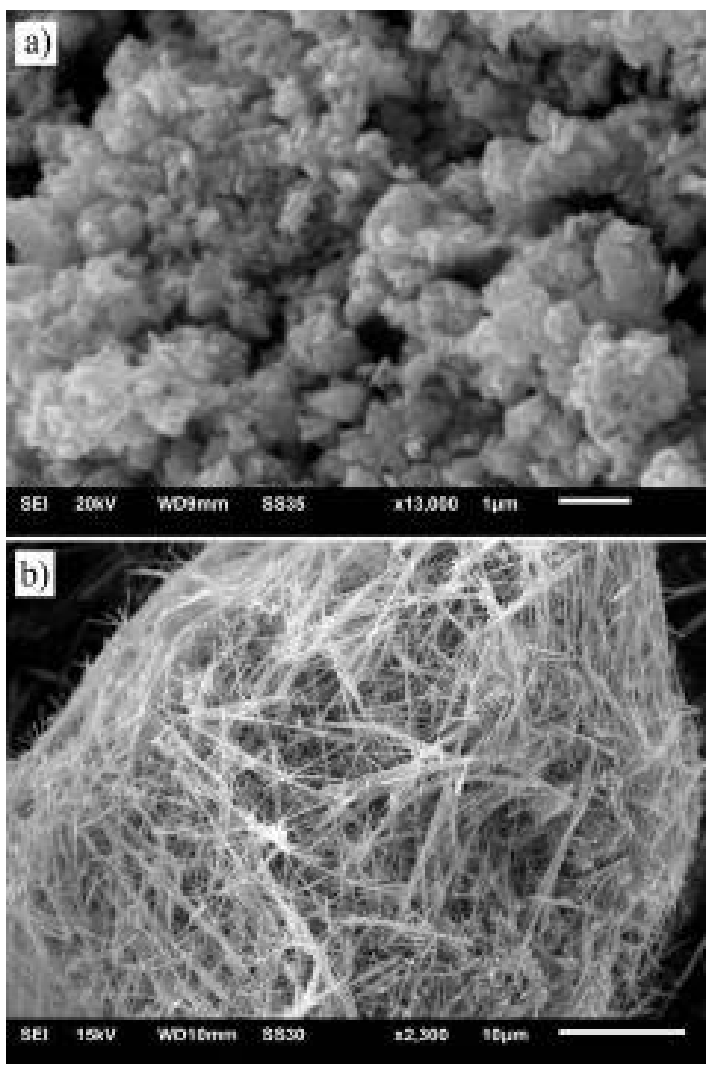

Figure 6. SEM images of: a) IF-WS 2 , b) INT-WS

The nanoparticles and nanotubes are evidently very agglomerated, but this problem is easily solved by ultrasonic irradiation before their direct application [17].

Representative results of tensile tests are given in diagrams in Figures 7 and 8, Tables 1 and 2.

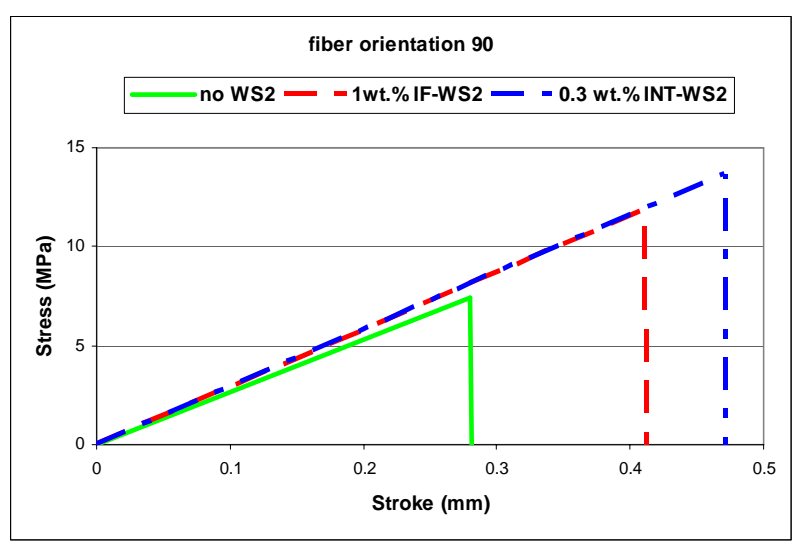

Figure 7. Tensile test results for composites with fiber orientation $90^{\circ}$

Table 1. Force, tensile strength, modulus of elasticity and elongation for composites with fiber orientation $90^{\circ}$

\begin{tabular}{||c|c|c|c|c||}
\hline $\begin{array}{c}\text { Sample } \\
\text { fiber orientation } 90^{\circ}\end{array}$ & $\begin{array}{c}F_{\max } \\
\mathrm{kN}\end{array}$ & $\begin{array}{c}R_{m} \\
\mathrm{MPa}\end{array}$ & $E, \mathrm{GPa}$ & $\begin{array}{c}\varepsilon, \\
\%\end{array}$ \\
\hline \hline No nano-reinforcement & 0,60 & 7,43 & 4,62 & 0,15 \\
\hline IF-WS 2 1 mas.\% $\%$ & 0,95 & 11,87 & 4,61 & 0,22 \\
\hline INT-WS ${ }_{2}$ 0,3mas.\% & 1,07 & 13,69 & 5,18 & 0,30 \\
\hline
\end{tabular}

Table 2. Force, tensile strength, modulus of elasticity and elongation for composites with fiber orientation $0^{\circ} / 90^{\circ}$

\begin{tabular}{||c|c|c|c|c||}
\hline $\begin{array}{c}\text { Sample } \\
\text { fiber orientation } 0^{\circ} / 90^{\circ}\end{array}$ & $\begin{array}{c}F_{\max } \\
\mathrm{kN}\end{array}$ & $\begin{array}{c}R_{m} \\
\mathrm{MPa}\end{array}$ & $E, \mathrm{GPa}$ & $\begin{array}{c}\varepsilon, \\
\%\end{array}$ \\
\hline \hline No nano-reinforcement & 42.48 & 542.35 & 175.19 & 0.31 \\
\hline IF-WS 2 1 mas. $\%$ & 38.98 & 529.37 & 199.77 & 0.25 \\
\hline INT-WS 0,3 mas.\% & 43.67 & 571.02 & 164.38 & 0.33 \\
\hline
\end{tabular}

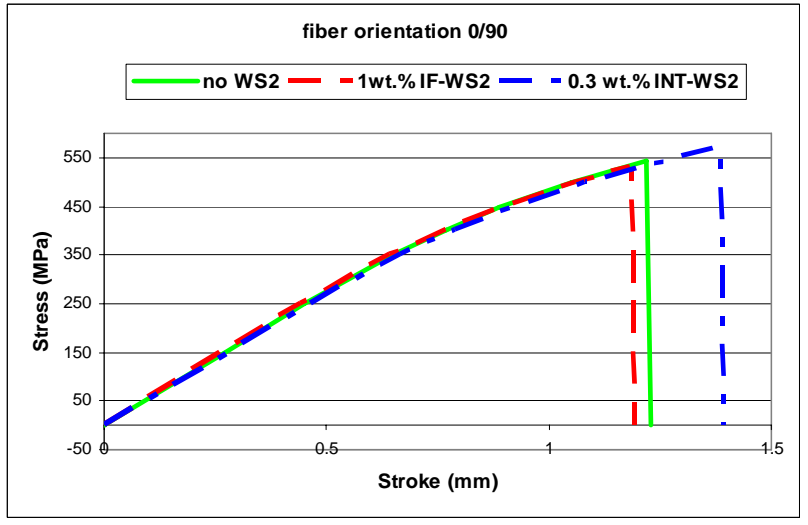

Figure 8. Tensile test results for composites with fiber orientation $0^{\circ} / 90^{\circ}$

From the presented results for the group of composite samples with the orientation of fibers $90^{\circ}$, it may be observed that the presence of nanoreinforcement has evidently improved analyzed mechanical properties, especially the presence of nanotubes. The best improvement was achieved with addition of $0.3 \mathrm{wt}$. $\%$ of INT-WS $\mathrm{W}_{2}$ : maximum force was increased for $78 \%, R_{m}$ was increased for $84 \%$ and modulus of elasticity is increased for $12 \%$.

On the other hand, for the group of composite samples with the orientation of fibers $0^{\circ} / 90^{\circ}$, results are very similar for the samples without nanoreinforcement and with fullerene-like nanoparticles, even we may note some decreased values of results for specimens with nanoparticles:tensile strength and modulus do not deviate more than few percent. The reason for this might be inhomogeniety of the samples due to human factor in production process, but it shoul be confirmed in further tests with larger number of specimens. This should also be further studied on different IF-WS $\mathrm{W}_{2}$ concentrations and with more different fiber orientations. In literature there are certain findings that some amounts of IF-WS $\mathrm{W}_{2}$ enhance toughness but degrade stiffness and tensile properties [22, 23], and the aim of researchersis to increase epoxy toughness without significantly sacrificing the glass transition temperature, the stiffness or the strength. However, analyzing the results, an improvement is observed for the sample with nanotubes: $R_{m}$ was increased for $5.3 \%$.

Generally, it should be noted that for the first orientation of the fibers, $90^{\circ}$, the values of the observed parameters are significantly lower than for the second orientation of the fibers, $0^{\circ} / 90^{\circ}$. This is expected since high modulus carbon prepreg was used and little contribution could be done in $0^{\circ}$ direction, but on the other hand $90^{\circ}$ orientation shows that improvents can be made in directions other than the main one, thus increasing the ovarall strength of aircraft composite structures.

\section{Conclusions}

Reinforced composites based on carbon fibers and epoxy resin were prepared, adding a small amount of poly (vinyl butyral), PVB and two kinds of nanostructures of tungsten disulfide, fullerene-like nanoparticles and multi-wall nanotubes. Two orientations of the fibers were applied: $90^{\circ}$ and $0^{\circ} / 90^{\circ}$. For the first type of fibers orientation, significant improvement of mechanical properties was observed with addition of both nanofillers, especially nanotubes: maximum force and elongation were increased approximately twice. For the second type of fibers orientation there were no significant differences in the results. In further research different fibers orientations should be examined, different nanoreinforcement concentrations, and a wider spectrum of mechanical tests will be performed. 


\section{Acknowledgments}

The paper is the result of the research within the project TR 36050 and TR 34034 financed by the Ministry of Education, Science and Technological Development of the Republic of Serbia.

\section{References}

[1] JONES,R.M., Mechanics of Composite Materials, Second Edition, Taylor\& Francis Inc., 1999.

[2] BAKER,A., DUTTON,S., KELLY,D.: Composite Materials for Aircraft Structures, SecondEdition, American Institute of Aeronautics and Astronautics. Inc, 2004.

[3] ILIĆ,I., ILIĆ,LJ., PERKOVIĆ,S., BLAZIĆ,M.: Strength Analysis Of Composite Structural Elements For Unmanned Aerial Vehicle, Fourth Serbian (29th Yu) Congress on Theoretical and Applied Mechanics, Vrnjačka banja, 4-7 Jun 2013, pp. 431-436

[4] MAKSIMOVIĆ,S., ILIĆ,I., GEORGIJEVIĆ,D., VASIĆ,Z., BOJANIĆ,M., STEFANOVIĆ,V.: Structural Analysis and Static Testing of a Tactical Unmanned Aerial Vechicle, ScientificTechnical Review, ISSN 1820-0206, 2013, Vol.63, No.2, pp. 58-62

[5] BRANTSEVA,T.V., SOLODILOV,V.I., ANTONOV,S.V., GORBUNOVA,I.Y., $\quad$ KOROHIN,R.A., $\quad$ SHAPAGIN,A.V., SMIRNOVA,N.M.: Epoxy modification with poly(vinyl acetate) and poly(vinyl butyral). I. Structure, thermal, and mechanical characteristics, J. APPL. POLYM. SCI. 2016, DOI: 10.1002/APP.44081

[6] http://www.kuraray.eu/en/produkte/productgroups/polyvinyl-butyral

[7] OBRADOVIĆ,V., STOJANOVIĆ,D., KOJOVIĆ,A., ZIVKOVIĆ,I., RADOJEVIĆ,V., USKOKOVIĆ,P., ALEKSIĆ,R.: Aramid composites impregnated with different reinforcement: nanofibers, nanoparticles and nanotubes, Zaštita materijala (Materials Protection), 2014, 15(4): pp. 351-361.

[8] DIMESKI,D., SREBRENKOSKA,V.: Advanced prepreg ballistic composites for military helmets, In: Proceedings of $6^{\text {th }}$ InternationalScientific Conference on Defensive Technologies OTEH 2014, Belgrade, SERBIA, 09-10 October 2014, ISBN 978-8681123-71-3, pp. 418-424

[9] BHATTACHARYYA,D.: Composite Sheet Forming, Composite materials series 11, Elsevier ISBN 0-444-82641-6, 1997.

[10] SIMIĆ,D., STOJANOVIĆ,D., BRZIĆ,S., TOTOVSKI,LJ., USKOKOVIĆ ,P., ALEKSIĆ,R.: Aramid hybrid composite laminates reinforced with inorganic fullerene-like tungsten disulfide nanoparticles, Composites: Part B: Engineering, 2017, 123,pp. 10-18.

[11] doi:10.1016/j.compositesb.2017.05.002

[12] TENNE,R., REDLICH,M.: Recent progress in the research of inorganic fullerene-like nanoparticles and inorganic nanotubes. Chemical Society Review 2010,39, pp. 1423-1434.
[13] TENNE,R.: Inorganic nanotubes and fullerene-like nanoparticles, Nat Nanotechnol1:103 (2006)

[14] TENNE,R., MARGUlis,L., GENUT,M., HODES,G.: Polyhedral and cylindrical structures of WS2, Nature, 1992, 360, pp. 444-446.

[15] TEVET,O.: Mechanical and tribological properties of inorganic fullerene-like (IF) nanoparticles, Weizmann Institute of science, Rehovot, Israel. (2011)

[16] KAPLAN-ASHIRI,I., TENNE,R.: Mechanical properties of WS2 nanotubes. Journal of Cluster Science, 2007, 18, pp. 549-563.

[17] XU,F.: Large Scale Manufacturing of IF-WS2 Nanomaterials and Their Application in Polymer Nanocomposites, University of Exeter, Devon, UK (2013)

[18] SIMIĆ,D., STOJANOVIĆ,D., $\quad$ KOJOVIĆ,A., $\quad$ DIMIĆ,M., TOTOVSKI,LJ., USKOKOVIĆ,P., ALEKSIĆ,R.: Inorganic fullerenelike IF-WS2/PVB nanocomposites of improved thermo-mechanical and tribological properties, Materials Chemistry and Physics 184: pp.335344 ,

[19] doi: 10.1016/j.matchemphys.2016.09.060

[20] LAZIĆ,D., SIMIĆ,D., SAMOLOV,A., JOVANOVIĆ,D.: Properties of standard polymeric and water-based coatings for military camouflage protection with addition of inorganic fulerene-like tungsten disulphide (IF-WS2) nanoparticles, Scientific Technical Review, ISSN 18200206, 2017, Vol.67, No.1, pp. 38-44.

[21] LAZIĆ,D., SIMIĆ,D., SAMOLOV,A.: Effect of IF-WS2 nanoparticles addition on physical-mechanical and rheological properties and on chemical resistance of polymeric coating and polyurethane paint, In Proceedings of 7 th International Scientific Conference on Defensive Technologies OTEH 2016, Belgrade, SERBIA, 6-7 October 2016. ISBN 978-86-81123-82-9, pp. 609-613

[22] SIMIĆ,D., STOJANOVIĆ,D., DIMIĆ,M., TOTOVSKI,LJ., BRZIĆ,S., USKOKOVIĆ,P., ALEKSIĆ,R.: Preliminary analysis of the possibility of preparing $P V B / I F-W S 2$ composites. Effect of nanoparticles addition on thermal and rheological behavior of PVB. In: Proceedings of 7th International Scientific Conference on Defensive Technologies OTEH 2016, Belgrade, 6-7 October 2016, ISBN 978-86-81123-82-9, pp. 618623.

[23] ASTM D 3039/D 3039M Standard Test Method for Tensile Properties of Polymer Matrix Composite Materials

[24] SHNEIDER,M., DODIUK,H., KENIG,S., TENNE,R.: The Effect of Tungsten Sulfide Fullerene-Like Nanoparticles on the Toughness of Epoxy Adhesives, Journal of Adhesion Science and Technology 24 (2010), pp. 1083-1095.

[25] ANUJA,K.H., POOJA,G.P., SIDHU,J.S.: Investigation Of Mechanical And Tribological Behaviour of $\mathrm{WS}_{2} \& \mathrm{ZrO}_{2}$ Filled Epoxy Composites, International Journal of Informative \& Futuristic Research, 2016, 3(12), pp. 4537-4550.

\title{
Analiza primene karbon-epoksi kompozita sa dodatim nano- strukturama volfram disulfida na vazduhoplovnim strukturama
}

\begin{abstract}
Pri projektovanju aviona važno je koristiti lagane, ali mehanički čvrste materijale. U tu svrhu razvijene su mnoge nove kompozitne strukture, uglavnom na bazi jakih vlakana i vezivne smole. $U$ ovom istraživanju razmatra se mogućnost pojačavanja kompozita na bazi karbonskih vlakana i epoksidne smole, dodavanjem male količine poli (vinil butirala), PVB i nanostruktura volfram disulfida. U eksperimentima su korišćene dve vrste nanočestica, obe poznate po dobroj mehaničkoj otpornosti: nanočestice nalik fulerenu i višeslojne nanocevčice, IF-WS I INT-WS $_{2}$. Uzorci kompozita su pripremljeni tako da se sastoje od višeslojnih karbonskih vlakana impregniranih sa epoksidnom smolom i PVB rastvorom koji sadrži definisane koncentracije dispergovanih nanostruktura $W_{2}$. Nanočestice su posmatrane skenirajućim elektronskim mikroskopom, SEM. Mehaničke osobine višeslojnih kompozitnih uzoraka testirane su sa dve konfiguracije pravaca vlakana. Analizirani su uporedni rezultati i izvedeni zaključci koji podstiču buduću primenu ovih nanostruktura u cilju poboljšanja performansi kompozita za vojne avione.
\end{abstract}




\title{
Анализ использования углерод-эпоксидных композитов с добавленными наноструктурами дисульфида вольфрама на конструкциях самолётов
}

\begin{abstract}
При проектировании самолёта важно использовать лёгкие, но механически прочные материалы. Для этой цели было разработано много новых композитных структур, в основном на основе прочных волокон и связующих смол. В этом исследовании рассматривается возможность армирования композита на основе углеродных волокон и эпоксидных смол путём добавления небольшого количества поли (винилбутираля), ПВБ и наноструктуры дисульфида вольфрама. В экспериментах использовались два типа наночастиц, оба известны хорошей механической стойкостью: фуллереноподобные наночастицы и многослойные нанотрубки, IF-WS и INT-WS $_{2}$ Oбразцы композитных материалов были изготовлены из многослойных углеродных волокон, пропитанных эпоксидной смолой, и раствором ПМБ, содержащим определённые концентрации дисперсных наноструктур WS 2 . Наночастицы наблюдали на сканирующем электронном микроскопе, СЭМ. Механические свойства многослойных композитных образцов были испытаны с двумя конфигурациями направлений волокон. Были проанализированы сравнительные результаты и сделаны выводы, которые стимулируют будущее применение этих наноструктур для улучшения характеристик композитов для военных самолётов.
\end{abstract}

Ключевые слова: композитные материалы, наночастицы, дисульфид вольфрама, эпоксидные смолы, углеродное волокно, конструкция самолёта.

\section{Analyse de l'utilisation des composites carbones époxy avec les structures nano du tungstène disulfure chez les structures d'aéronefs}

\begin{abstract}
Lors de la conception de l'avion il importe d'utiliser les matériaux légers mais solides mécaniquement. A cet effet on a développé de nombreuses nouvelles structures composites généralement basées sur les fortes fibres et les résines liantes. Dans cette recherche on considère la possibilité du renforcement des composites à la base des fibres carboniques et de la résine époxy avec l'addition d'une petite quantité de poly(vinyle butyrale) PVB et des nano structures du tungstène disulfure. Pendant les examens deux sortes des nano particules ont été employées, toutes les deux connues par la forte résistance mécanique : nano particules pareilles à fullérène et nano tubes multicouches IF-WS2 et INT-WS2. Les échantillons des composites ont été préparés pour comporter des fibres carboniques multicouches imprégnés par la résine époxy et par la solution PVB qui contient les concentrations de nano structures WS2 définies et dispersées. Les nano particules ont été observées par le microscope électronique scanne SEM. Les propriétés mécaniques d'échantillons composites multicouches ont été examinées par des configurations de la direction des fibres. Les résultats comparés ont été analysés et les conclusions incitant aussi l'emploi futur de ces nano particules ont été faites afin de pouvoir améliorer les performances des composites pour les avions militaires.
\end{abstract}

Mots clés: matériaux composites, nano particules, tungstène disulfure, résines époxy, fibre carbonique, structure d'aéronef. 